\title{
Hermeneutics and the "Classic" Problem in the Human Sciences
}

\begin{abstract}
There has been a longstanding and acrimonious debate in the human sciences over the role played by classic texts. Advocates of the classic insist its value is timeless and rests on the intrinsic superiority of its cognitive insights and aesthetic virtues. Critics, by contrast, argue that the respect accorded the classic is spurious because it conceals the ideological assumptions, tensions and discontinuities of tradition. This paper seeks a solution through the account of 'the classical' brought by Hans-Georg Gadamer in Truth and Method, which acknowledges a text's 'eminence' as well as its 'historicity'. Following the introduction, the paper divides into four sections. Section one, notes that the hermeneutic account of tradition describes it as being open to challenge rather than closed and unchangeable, and that the classic, as grounded in tradition, will conserve difficulty as readily as comfortable certainty. Section two focuses on the idea that in the classic we find matter 'properly portrayed', while section three notes the importance of 'application' for an understanding of classic texts. It is noted that both 'proper portrayal' and 'application' depend on recognising the role of the fusion of historical horizons in generating classic texts. The final section challenges the criticism that the classic is no more than a reflection of the institutional power wielded by the canon, arguing instead that the classic and the canon are different entities, and conflating them in favour of the latter, misleadingly reduces classic-ness to being no more than an effect of canonicity.
\end{abstract}




\section{Hermeneutics and the "Classic" Problem in the Human Sciences}

Influential as they are, deconstruction and postmodernism are only symptoms, bright bubbles at the surface of a mutation. It is, as I have suggested, our elemental perceptions of death, our time-sense, of the related classical impulse in art and poetry to endure, to achieve timelessness, which are today in radical question.

(Steiner, G. 1997: 156)

\section{Introduction}

\section{The Sense of an Ending ${ }^{1}$}

If getting a bad press foreshortens a text's life, the demise of the classic is long overdue. In the last thirty years, there have been thoroughgoing, sometimes vitriolic critiques of classic texts and equally vehement ripostes, notably in Literary Studies ${ }^{2}$ and more recently in Sociology ${ }^{3}$. Ostensibly, the dispute centres on whether classic texts should retain their status as constituting a canon of great works with which all students should become familiar, or be discarded in favour of something more recent and relevant. The debates have often been intensely political, as much reflecting the way the protagonists see their identity as the qualities of the texts themselves. In the course of these debates even the word 'canon' seems to have changed its 
meaning. Where once it was a placid, descriptive term, suggestive of little more than the collective works a discipline held in high regard, it is now altogether more contentious. For its advocates it is something to be cherished because the virtues of the classics are self-evident. Writing of Sociology's classics, (Weber, Durkheim, Marx), Gianfranco Poggi (1996: 39-40) declares 'their unique intellectual texture [and] the magnitude of their scholarly achievement' means that we do our students a disservice if we do not bring them into contact with these texts; 'they are simply the best stuff the discipline of sociology has produced in the course of its history'. From the angle of Literary Criticism, Harold Bloom (1994) writes similarly, though much more polemically in favour of the literary canon as an unproblematic fixation of all that is great in great Literature. Unrelentingly he inveighs against those cultural materialists, feminists and new historicists who would undo the hierarchy of the western literary canon, based as it is on the timeless virtues of cognitive acuity and aesthetic excellence. He rails against those in the 'School of Resentment', as he calls it, who historicize the artwork or otherwise put context ahead of it. The resulting conflation involves a loss of the distinction between the aesthetic and the social. Such authors reduce Shakespeare to being an effect of the 'social energies' of the English Renaissance and are thus unable to distinguish between the creator of Lear, Hamlet, and Iago, and his disciples, John Webster and Thomas Middleton ${ }^{4}$ (1994: 3).

For its critics, though, 'canon' is a dubious, prescriptive term, one that represents the insidious privileging of the values of white, western, middle-class males. Arguing that it is a dusty relic of something 'other people, once powerful have made', many disparage its value, insisting that it should be 'opened up, demystified, or eliminated altogether' (Hallberg 1984: 1). Functioning in the same exclusionary way that Lyotard (1984) designated Western 'metanarratives', critics claim that canons tacitly affirm the rightness of things as they are by squeezing the possible value of other, non-canonical voices to the margins. Moreover, the fact that there are threads of religious meaning that still cling to the idea of a canon, quickly incites the full weight of the hermeneutics of suspicion against it. Unsurprisingly, in this climate the worth of the classic shrinks back. Now shy of affirming its quality, its persistence seems to be sustained only by the inertia of fixed university curricula, which according to Bourdieu (1988: 100), serve to reproduce the 'habitus' of the 'consecrated professors' and 'oblates' of the 'canonical 
disciplines' of (French) higher education. Bourdieu's canonical disciplines are French Literature, Classics and Philosophy, rather than Sociology ${ }^{5}$, but the critical point remains the same: canons function as 'instruments of cultural power, inasmuch as they are an enterprise in the prescription of knowledge and the canonization of the legitimate heritage' (1988: 102). While Bourdieu's ideas are more subtle than these polemical quotations might suggest, for critics generally attention shifts from considering whatever inherent merit a classic might have, to assessing how well it affirms, or more often does not affirm, current values. Those who would celebrate its virtues are on the back foot, defensive of something they fear is ending anyway. As a literary figure who affirms the canon, George Steiner believes he has grasped this sense of an ending 'too late in the day'. He looks back melancholically on a career, which has been devoted to the transcendent qualities of the classic tradition of Western art, declaring that his scholarly work now seems like 'an in memoriam, a curatorship of remembrance' (1997: 156). If this tradition is dissolving as he claims, then those who continue to find value in classics are little more than museum keepers, pointlessly preserving things in the face of their inevitable demise.

In this paper I want to challenge Steiner's pessimism by examining the contribution Gadamer's account of 'the classical' in Truth and Method (1989), makes to an understanding of the issue. Rather than anticipate the demise of the classic, I want to suggest its likely persistence. I shall argue that Gadamer's description of classic-ness (or classicity) acknowledges the possibility, both of a text's 'eminence' and its 'historicity': the two opposing poles at the heart of the dispute. In this, I believe, the Gadamerian account surpasses both Bloomian advocacy and Bourdieuian dismissal of classic texts. My claim is that Gadamer successfully reveals the interdependence of these elements without sacrificing one for the sake of the other, or otherwise conflating them.

Tradition as the Ground of the Classical

It is not coincidental that in Truth and Method Gadamer's account of the classical follows on immediately from his provocative 'The Rehabilitation of Authority and Tradition' 
(1989: 277ff). The implication is that the classic speaks to us authoritatively through tradition. The provocation of this account lies in what authors as varied as John Caputo, Terry Eagleton and Jürgen Habermas regard as the conservatism implicit in Gadamer's 'tradition'. For Caputo, he is guilty of a 'closet essentialism', where tradition serves as a half concealed, but ultimately all resolving, metaphysical source of truth. There is, Caputo claims, a complacency in Gadamer's account that is too trusting of tradition; it requires us to let tradition have sway so we can be more thoroughly at home in it (1987: 258-64). Though Eagleton comes from the angle of Marxism rather than Caputo's deconstruction, he expresses something similar. Tradition, he declares, is a site of oppression, conflict and domination and not, as he chides Gadamer for believing, an untrammelled, 'ever-flowing river' that functions as a 'club of the like minded', where art means chiefly 'the classical monuments of the high-German tradition' (1983: 72-73). Habermas also, in his famous debate with Gadamer, took issue with the hermeneutic account of tradition, insisting that adequate reflection guided by Critical Theory could, and should, dissolve the illegitimate power exercised by tradition (1988: 168-70).

However, Habermas' engagement with hermeneutics was always more nuanced and sympathetic than that of other critics. In a recent public speech, for example, he expressed a view of the classic similar to that brought by Gadamer forty years earlier. $\mathrm{He}$ notes that for the works of great thinkers, the context of their lives recedes in the face of the unique formulations of their ideas. Using a fiery metaphor, Habermas (2004) declares that classics, far from being something passively received from tradition, are like 'the molten core beneath a volcano around which the rings of [the author's life] have hardened like scoria'. Classics, he says, are works over which 'later generations repeatedly tussle', and have the odd capacity to remain 'contemporary to this day'. In contrast, the less original a philosopher's ideas are, 'the more they remain entrenched in the context from which they emerged'. Implicit here is the notion that the classic is not something imposed on succeeding generations by the dead hand of tradition, but a volatile phenomenon, capable generating heat and light in an ongoing struggle for meaning. On this account, the classic is not a flat reiteration of the past, but something that in the playing out of differences between it and our current prejudices throws up 
sparks of light illuminating the present and its possible futures. Insofar as classic texts are expressions of tradition, then tradition, like the classic, is as much the bearer of challenge as of comfortable certainty.

Gadamer's critics have paid little attention to the side of his work that sees challenge and critique as much a part of tradition as the supposedly cosy beliefs critique would overthrow. One suspects that because Gadamer's philosophical style is conversational and questioning rather than polemical and adversarial his response to the charge of 'conservatism' appears less decisive than it actually is. In his reply to Habermas, Apel and others, for example, he noted only that they had misunderstood his phrase: 'much depends on establishing a connection with tradition', which did not imply a preference for the merely customary. The revolutionary desire to alter existing conditions, no less than the defence of them was, he declared, indicative of our connection to tradition, for 'tradition exists only in constantly becoming other that it is' (1990: 288-89). Both 'revolutionary' and 'customary' presuppositions could be legitimate, but such legitimacy was something to be decided within the particular reflective practices of tradition and not derived directly from philosophical hermeneutics. His account of tradition, he emphasised, was ontological, and thus 'not about what we do or what we ought to do, but what happens to us over and above our wanting and doing' (1989: XXVIII).

One author to have recognised the implications of this wider and potentially more recalcitrant notion of tradition is Nicholas Davey (2006). He affirms the importance of 'difficulty' as something immanent to the Gadamerian conception of tradition. Conceived this way, tradition is indeed conservative, but thus because it conserves difficulty, rather than eliding it. Difficulty regularly emerges within tradition, not as a threat, but as 'one of its drivers' (2006: 50-54) ${ }^{6}$. A healthy, living tradition, he argues, embodies 'continuities of conflict': a situation where the arguments over a tradition's 'goods' are what gives that tradition its particular point and purpose. Certainly, critics of philosophical hermeneutics are often forgetful of the way the sources of their own challenge to tradition lie within tradition. To this end, Gadamer (1989: 262-64) notes that for us to question something, it must already be questionable; tradition must already have put that 'something' in 
question for it to address us as problematic and be something in need of a response. The question, as it were, brings into the open something to which we have already been alerted by tradition.

To imply, as critics do, that tradition directly transmits the past into the present, as an unsolicited, if avoidable, imposition, misunderstands the ontological relation of the past to the present. It also elides the interpretive density manifested by a living tradition in its co-presence with the past. For Gadamer, the presuppositions or pre-judices of tradition are not the burdens of the past but those first, active ingredients through which the present and the future exist. The status of these presuppositions is not psychological but ontological; they are the elements that 'constitute the initial directedness of our whole ability to experience'; they are 'the very biases of our openness to the world' (1976: 9). In this, they are not closed doors, but the primordial pathways through which, in a sense, we have a world at all. Moreover, the primacy attributed to our current 'prejudices' is no indication of automatic obedience to them, for they are not 'a set of fixed opinions and valuations', but exist in conjunction with those of the past or other horizons (1989: 306). The prejudices that make up the horizons of the past are linguistical in character, and in this, address us as an interlocutor would, as a 'thou' in a dialogue. Thus, a necessary feature of hermeneutic understanding involves being open to the effects of the other's 'otherness', even of amplifying the alterity of the horizons of the past or of the alien text as they come into conjunction with current assumptions. While Gadamer refers to this conjunction as the fusion of horizons, he warns against any notion of an unmediated assimilation of one to the other. Indeed, for hermeneutics, the horizons of past and present are never complete or fixed, but always partial and malleable. They exist only in a processual state. Central to this process is the interpretative space that exists in tension between these putative horizons as they come into conjunction. For Gadamer, the playing out of this tension is hermeneutically important and something we should deliberately explore:

Every encounter with tradition that takes place within historical consciousness involves the experience of a tension between the text and the present. The 
hermeneutic task consists in not covering up this tension by attempting a naïve assimilation of the two, but in consciously bringing it out. (1989: 306)

It is in the play between the present and the past, the familiar and the unfamiliar, the canny and the uncanny, that the interpretive possibilities of classic texts show themselves most thoroughly. The classic-ness of the classic, so to speak, has its source in the disjunction created by the virtual space between horizons. The perplexing fact that classic texts are still able to speak meaningfully to audiences far removed in time and place from the original ones, exemplifies the transformative qualities of this space, grounded as it is, not in the text itself, but in the movement of tradition.

\section{The Classic Text}

Gadamer (1989: 285-90) discusses the classic text in the broader framework of the changing nature of 'the classical' as it relates to the workings of tradition. He traces the interplay between two alternative notions of 'the classical', one referring to the historical epoch of Greek antiquity, the other to something held in high esteem. Where once the two meant virtually the same thing, the effect of modern "historical consciousness" in which things are seen only as expressions of (historical) context, has been to diminish the latter with its concern for normative value. Yet despite the tendency to dissolve the classical into being merely a description of a period of time or historical style, its evaluative dimension has never quite subsided. Taking as his starting point 'the living meaning that resides in language as it is used', he notes the common exclamation, 'that's classic!', as something that works perfectly well and without any metaphysical artifice in ordinary language. It means that one 'will hear [something]...again and again, see it again and again, read it again and again, and it will be right again and again' (2001: 65, original emphasis). Certainly, in everyday life, we talk unselfconsciously about classic films, classic sporting events, even of classic TV comedy shows. By which we mean that these artefacts or events (texts) exemplify more completely than others, the unities and the virtues of a particular activity. They are as it were, the most complete realisation of a 
particular social practice, and something that persists beyond the initial encounter in the imaginations of those that experience it.

While the normative sense of the 'classical' is the important one for philosophical hermeneutics, being undermined by 'historical consciousness' has actually produced a positive effect. The historicization of the concept has liberated it from referring to only one thing. Instead of just referring to the unsurpassable virtues of ancient Greece, it now extends to fields wherever a text achieves eminence. The value of the classic now is neither an eternal verity, nor merely something from the past that has long gone. In whatever form the classic now takes, we find 'eminence' and 'historicity' happening together.

In terms of the human sciences, Gadamer notes that the large amount of research data that has accumulated in the last hundred years should make the work of its earlier, less wellinformed authors, redundant. Yet often one prefers to read their work rather than something more recent, even when the latter is empirically better informed. There is something odd in this as one would expect the empirical limitations of the older text to restrict our understanding of things; one would expect the picture it drew up to be inferior and less enlightening than the newer one. However, this is not necessarily the case. Gadamer has in mind the work of the $19^{\text {th }}$ century historians, Droysen and Mommsen when he argues that we can easily make allowances for the limitations of the knowledge available to them and still find their work more decisive than recent publications. This phenomenon is not peculiar to history writing. Discussing the centrality of the classic text in contemporary sociology, Jeffrey Alexander points to the same thing. Attributing the status of classic to a text, he argues, 'means that contemporary practitioners of the discipline...believe they can learn as much about their field through understanding this earlier work as they can from the work of their own contemporaries' (1987: 12). It may not be correct in some detail, but sociologists accept the classic as classic because in throwing light on a particular subject matter in a particular way it has set out the criteria by which that field is knowable. This is so, Gadamer deems, because in the classic text we find subject matter 'properly portrayed'. 
The rather enigmatic phrase 'properly portrayed' bears on the nature of the human sciences, which Gadamer marks off from the natural sciences. The cumulative results of research in the natural sciences drive those disciplines forward. They pursue knowledge of their 'object' teleologically on the basis that nature can ultimately be known in-itself. Gadamer acknowledges that since the advent of the post-empiricist philosophy of science, which emerged after the publication of Truth and Method, this formulation looks too undifferentiated (1989: 283 note 209, 285 note 211). Nevertheless, while many now think the differences between the human and the natural sciences were previously overstated, the contrast Gadamer draws between them is still instructive at the level of practice.

In the human sciences, we do not face an 'object' in the same observational way that is characteristic of the natural sciences. It is more accurate to say that in the human sciences the 'object' addresses us, implying that from the start a dialogic relationship exists between it and the researcher. This is because in the human world the historical horizons of tradition play a constitutive role in the formation of both parties. Both the 'objects' that address us and we ourselves are formed in the process of an ongoing dialogue between the pre-judices of the present with those of the past, or with other unfamiliar horizons. Because both entities exist and only exist within these finite horizons, there is no fixed 'object' for the human sciences to grasp in a way comparable to those of the natural sciences. Habermas had once coined the phrase, 'stance of the last historian' as a heuristic device for overcoming what he saw as the vagaries of hermeneutic social science. If we exist through the horizons of our historical tradition, he argued, then only at the 'end of history', when meaning-change had ceased and everything that was going to happen had happened, could we know things objectively. In the absence of history being at an end, the task for the hermeneutic social scientist should be to adopt the attitude of the 'last historian' and write in anticipation of a 'hypothetical totality of preunderstood universal history' (Habermas 1988: 155-61). Nevertheless, writing history or anything else in hypothetical anticipation of a perfect end-state was for Gadamer the 
pursuance of a positivist chimera involving a denial of the finitude of human life-practice (How 1995: 128-32).

By contrast, for hermeneutics, the working out of tradition in terms of the fusion of horizons means that the 'objects' of the human sciences are knowable in a different way. They are knowable not absolutely, but mediately, i.e. through the mediation of historical horizons. They present themselves in different ways at different times and from different standpoints, though they do not cancel each other out as research proceeds and more data is gathered. Rather, we recognise the multifarious voices that make up the horizons of tradition and accept that these shape the very nature of the subject matter. A cursory glance at the historiography of the French Revolution serves as an example of how the meaning of the events of 1789 open up differently in the light of subsequent horizons. From the horizon of Marxism, Albert Soboul and Daniel Guérin have argued that it was the definitive bourgeois revolution. In this, an emerging bourgeoisie briefly harnessed the power of the masses for its own interests, only to betray them because as an embryonic proletariat they would pose a threat to those interests. In contrast and drawing on a different ensuing horizon, Robert R. Palmer and Jacques Godechot argue that the French Revolution should be seen alongside other eighteenth century revolutions in Western Europe and North America as heralding the emergence of democracy in the Western world (see Amman 1962). Thus, the truth of the French Revolution is not one thing that eliminates others, but several that emerge retrospectively only in the light of the succeeding horizons. Without the current horizons of 'capitalism' and 'democracy', the truths elicited by these historians could not have come into existence. There may be issues of fact to be resolved through further research, but interpretation is the decisive element in the human sciences.

The primacy of interpretation and its relation to the movement of tradition carries over into the idea that the classic text portrays its subject matter properly. This 'proper portrayal' refers to the capacity of the classic to disclose the significance of its subject matter more completely than other texts. As Gadamer (1989: 284) remarks: 
...subject matter appears truly significant only when it is properly portrayed for us...it acquires its life only from the light in which it is presented to us.

It is tempting to assume that this disclosive quality is something inherent in the text and the 'significance' disclosed a supra-historical truth. While this is not so, there have been critics who have suggested that it is so and represents a contradiction in Gadamer's work. Hans Jauss for example, has argued that when Gadamer quotes Hegel to the effect that 'the classical interprets itself' and is able to speak to every present generation as though it were speaking specifically to it, he is denying the central tenet of his own account, namely the role of the effects of history in all understanding. Thus for Jauss, the immediacy with which Gadamer assumes we can grasp the 'eminence' of a classic text is at odds with the importance he attributes to its 'historicity' (1982: 31). Jauss believes that Gadamer overcomes this tension by unwittingly attributing an atemporal, transcendental status to the meaning of the classic. For Jauss, at least the early Jauss ${ }^{7}$, Gadamer makes the classic appear as a monument that preserves the same truth for succeeding generations. Like other critics at the time, Jauss was challenging the apparent conservatism of a view that makes classics the bearers of eternal verities that sustain the cultural-political status quo.

This, however, is a misunderstanding of Gadamer's case. Certainly, he agrees the classic text appears timeless in that it seems to speak directly to each generation, but 'this timelessness', he declares, is 'a mode of historical being'. He means by this, that the fusion of historical horizons provides the medium through which the classic evokes awareness that we share something with its world and it something with ours. The classic discloses how much tradition is always with us, indeed within us. In this, it represents a challenge to the status quo, calling into question the omnipotence of the present and the assumption that our current powers of critical reflection are automatically superior to what has gone before. In a sense, we do not wholly choose what counts as classic; rather, the movement of tradition evinces the sense of the text's contemporary significance. For Gadamer, neither texts nor readers are fixed entities; both are subject to the temporal movement of the fusion of horizons. In fact, to show that it conserves something true 
from the past into the present, the classic has constantly to prove itself anew by speaking differently to succeeding generations. It has to come alive again within in the network of prejudices that make up the current horizon (Gadamer 1989: 287). One might say that like tradition the classic reveals its continuity with the past not by repeatedly being the same, but by repeatedly becoming different. It is this sameness-in-difference, which is at the heart of the hermeneutic case for the persistence of the classic text.

\section{Understanding and Interpreting means Applying}

Because of its semantic autonomy, the classic does not require a reconstruction of the original historical horizon as a precondition for its understanding. It carries its historicity within, actualising its potential across boundaries. In terms of a musical classic, for example, Gadamer (2001: 65) notes that:

...we know that Beethoven's Ninth Symphony arose in a certain context in musical history and intellectual history and is only to be understood historically in this context. And yet what the Ninth Symphony signifies for our understanding is far more than a system of tasks in historical reconstruction. .......the work is not first a testimony to something else that we have first to interpret; rather the work itself addresses us just as if we were its first hearers. We hear Beethoven's music, and in the hearing there is a true participation, which I expressed in Truth and Method with the concept of Zugehörigkeit (belonging).

This 'belonging' means not only belonging to a (musical) tradition but also the belonging of the listener to the work itself. The way we belong to, or engage with the classic also reflects the way the same text is enlivened differently amid the different prejudices of succeeding horizons. Hence, in the same way that the movement of tradition can be characterised as 'sameness-in-difference', so also it is with the process of actual interpretation. Drawing on the history of hermeneutics, Gadamer shows how this happens in terms of the inner connection between understanding, interpretation and application. 
In the pre-romantic hermeneutics of the $18^{\text {th }}$ century, he observes, 'understanding' and 'interpreting' were two separate activities (1989: 184ff). Hence, assuming one was broadly familiar with the subject matter, a text could be understood immediately and interpretation would only occasionally be necessary if that understanding was found wanting. In this hermeneutic outlook, understanding focused on the subject matter of the passage or text. The later idea that a text's meaning is the product of its author's intentions within an alien historical context and therefore something obscure, had not yet arrived. The $19^{\text {th }}$ century romantic hermeneutics of Schleiermacher and Dilthey brought this notion to the fore, finding the idea of ordinary, immediate understanding problematic. Such understanding was regarded with suspicion because it ignored the psychology of the author or the mediating effects of historical culture on the text. Such immediacy, it was argued, could easily be misleading and thus require revision through correct interpretation. In fact, the assumption grew that misunderstanding was the norm and interpretation always necessary. The aim of Schleiemacher's hermeneutics, for example, was to uncover the correct meaning of a text by establishing the grammatical and psychological rules of interpretation and thus to 'avoid misunderstanding at every point' (1998: 29). Subsequently, understanding has come not only to need interpretation, but also to presuppose it. For many now, to understand something is to interpret it.

Gadamer is in agreement with the idea that understanding and interpretation are reciprocal and inseparable. He is less happy with a formulation that sees the 'objective' meaning of a text as a function of the author's (psychological) intentions in the historical milieu of the time. This 'functionalist' form of reasoning side steps any engagement with the truth or validity of what the text says for the sake of reconstructing what the original author intended and his or her public understood. Nor is this outlook peculiar to $19^{\text {th }}$ century hermeneutics. Jauss' criticism of Gadamer rests on what he sees as the necessity of reconstructing the historical horizon of the text's original audience. Similarly, in the Anglophone history of ideas, Quentin Skinner (1969: 3-53) set his work in opposition to an outlook made famous by A. O. Lovejoy. Lovejoy argued that the history of ideas should focus on the way the same unit-ideas have travelled through time combining and 
recombining with others in various ways but remaining essentially the same. In contrast, Skinner argued for a fundamentally contextual view of historical ideas. For him, whatever in a text does persist over time, it is not the same original unit-idea. In his methodology, the aim is to fix the text's original meaning by focusing on what the author intended in writing that text, in that way, at that time, with that particular audience in mind. While the aim of reconstructing the original context 'as it was', may be a valid project for history writing, such radical contextualism misses out a key element in Gadamer's hermeneutic account, namely, the inevitable part played by 'application'.

For hermeneutics, there is a common blind spot in the otherwise diverse approaches of Jauss, Schleiermacher and Skinner. What eludes them is any sense of that initial belonging to, or engagement with a text, which necessarily happens in the process of understanding it through the prejudices of the current horizon. Those who seek a methodology that will give them an 'objective', presuppositionless view of a text's original meaning are denying the effectiveness their own contemporary horizon has in shaping that view. Trying to efface the effects of one's own horizon to build a methodological bridge from which to view the past unhindered by the prejudices of the present is for Gadamer, a positivist illusion. We cannot understand the meaning of a text, classic or otherwise, independent of the significance it has for us today. To understand a text is to understand the claim it makes on us. Only by letting the text address us through the prejudices of our current horizon, and by allowing the continuities and discontinuities between its claims and our prejudices emerge and play out, is this achieved.

To show the role of application in this 'playing out' Gadamer draws us back to the ideas of the $16^{\text {th }}$ century Pietist thinker, J. J. Rambach who divided hermeneutics into three subtilitas's or finesses: subtilitas intelligendi (understanding), subtilitas explicandi (interpretation), and subtilitas applicandi (application) ${ }^{8}$. These subtilitas's are not methods to be applied in the modern positivist sense, but subtleties of mind, which need to be practised for them to disclose their efficacy. For Gadamer what is important is to recognise the inner connectedness of all three as moments in the overall hermeneutic process. While the inner connection between understanding and interpretation has 
become familiar, the role of 'application' in the process has become virtually invisible. We now tend to think of 'application' only in instrumental terms, such that we talk of understanding something and applying it subsequently to something else for particular purposes. This assumption however, has bypassed an earlier, more primordial aspect of application, one that happens in the first moment of understanding. There is a reflexive moment in understanding such that in understanding something we implicitly apply it to ourselves in our own situation. If, for example, we hear a joke in a foreign language, for the humour to work it is not enough just to know the literal meaning of the words, we must imperceptibly translate it into the norms and values of our own culture. Only when the application indiscernibly crystallises within the network of meanings that constitute our own lives will the humour work and laughter follow (see How 1995: 59-77).

Gadamer takes his examples of the way 'application' links with 'sameness-in-difference', from legal and theological hermeneutics. In order for the same legal or religious texts to be understood properly, he notes, they must be applied differently in each new situation. For judges to act justly, rather than repeatedly applying the (same) letter of the law, they must understand how the spirit of the law applies differently in different situations. Similarly, for religious texts from the past to be understood properly, their spiritual dimension has to be concretised in a way that continues to evoke a sense of the holy in contemporary situations. He puts it like this

... the gospel does not exist in order to be understood as a merely historical document, but to be taken in such a way that it exercises its saving effect. This implies that the text, whether law or gospel, if it is to be understood properly - i.e. according to the claim it makes - must be understood at every moment, in every concrete situation, in a new and different way. Understanding here is always application (1989: 309).

The classic, like the religious or the legal text, or indeed the foreign joke, has to be reawakened and understood differently on each occasion to show its worth. The content of the classic does not express a 'supra-historical value', but is something that 'through 
constantly proving itself, allows something true to come into being' (1989: 287). In a sense, it is almost misleading to talk of the classic text per se because Gadamer's concern is with 'classicity', or the possibility of something being classical, rather than with the substantive qualities of any particular text.

Nevertheless, critics opposed to the role played by classics point to the way certain texts are canonised and thence uncritically passed down from one generation to the next. Canons, they argue, provide a network of ideological support that keeps an admiring gaze focused on certain texts and away from others not included in the canon. Such criticism, however, I believe conflates two different entities: the classic and the canon.

\section{Classics versus Canons}

In 'Why is Classical Theory Classical', R. W. Connell (1997) sets out to debunk the canonical status of sociology's classic authors: Weber, Durkheim and Marx. The originary myth to which sociology holds, Connell claims, is that in response to the rapid changes wrought by modernity, these canonical authors were able to produce the exemplary texts around which the discipline still builds its identity. Yet at the time of their writing, such authors were held in neither high nor low esteem, they were simply amongst a range of contributors whose work entered piecemeal into sociology. It was only after the Second World War when the main site for sociology's development moved to the USA their canonisation took place. The rapid expansion of higher education at that point meant that sociology required a canon of key authors to underpin its taught programmes. In this environment, Talcott Parsons played a central role in enshrining Weber and Durkheim as canonical, while C. Wright Mills and Lewis Coser established the credentials of Marx and Simmel. For Connell the sociological canon is thus not the outcome of the self-evident virtues of its authors' work, but the result of contingent decisions made subsequently by other sociology players in a particular set of circumstances. Moreover, the effect of this arbitrary canonisation has been to shape the kinds of question sociologists ask by defining what is to count as a sociological topic and 
the vocabulary in which it is to be discussed. Despite the title of Connell's article, its real concern is not with why classical theory is classical, but with the contingent empirical history of a text as it is canonised. Connell's approach effectively silences the classic by subsuming it under the process of canonization. For Connell, classicity is canonicity. While referring to the classic often implies reference to the canon, conflating the two in favour of the latter elides important differences. If we make an analytical distinction between the two, something different emerges.

Joel Weinsheimer (1991: 129-32) notes the significance of the asymmetrical grammar surrounding the terms. The canon is a collective noun embracing a group of authors or works that have a common cultural status. There is though, no noun referring to an individual work or author, there is only the adjective 'canonical'. The reverse is true of the classic, which is a singular noun denoting qualities attributable to a particular work or author. There may be more than one classic, but we can only pluralize the word by adding an 's'; there is no collective noun for the classics. A similar contrast exists with the verb to canonise. We can talk of the role Parsons and others played in canonising Weber, Durkheim and Marx, but there is no equivalent verb to 'classicise'. We cannot make a work classic. Its quality, as classic, refers to the virtues attributed to it in the process of subsequent interpretation. The two terms, 'classic and 'canon' thus refer to different things.

While 'canon' is a plural noun, it is determinate. We can say objectively what is 'in' or not 'in' the canon at any particular time by examining the frequency with which certain authors appear on university curricula, on student book lists, or if their work is regularly discussed in the discipline's basic textbooks. By including certain authors, the canon necessarily excludes others, but it is far from impermeable and can expand to include many more. William Outhwaite (2009) recently suggested that the canon in British sociology has expanded in the past thirty years beyond the famous three (occasionally four, with Simmel), to include Bauman, Beck, Bourdieu and Giddens. Habermas and Foucault, he notes, could also be added to the list, though they sit less squarely within sociology (2009: 1039 note 5). Despite the claims of critics, and as may be adjudged by 
the diverse nature of these authors, the canon is neither ideologically homogenous, nor closed to newcomers. Moreover, its contents, unlike those of the classic, are matters of fact.

If declaring something to be canonical can be demonstrated by reference to empirical evidence, the claim that something is classic requires a different kind of justification. In contrast to 'canon', 'classic' is a singular noun but indeterminate in the sense that it presupposes not a factual state of affairs but implies a judgement about the ongoing worth of a particular author or text. What is classic is open-ended in a way that what is canonical is not. Canons have a finite number of authors or texts, whereas there are potentially an infinite number of classics. Regarding something as classic involves actively judging its worth as exceeding that of other things. On the account I have drawn from Gadamer, it involves recognising that certain texts preserve something that remains valid today even while referring to a world different from the present. In this, for the classic to be classic, it has constantly to prove its validity in the here and now. Of course it may fail to prove itself, and if its qualities lose significance for us, its status as classic will dwindle.

The analytical distinction between classics and canons enable us to see that they are not necessarily synonymous. It becomes possible for something to be canonical but not classic, or classic but not canonical. For example, in the past sixty years, Durkheim may have been canonical in sociology, but not always thought classic. While the importance of his work has been acknowledged regularly on historical grounds, those in the 1960s who conceived sociology in a quite different, 'interpretive' way, such as Douglas (1971), saw no reason to accept his ideas. Durkheim's work has been regularly dismissed as positivist, and/or conservative, and as an exemplar of sociology being led into an intellectual a cul-de-sac by ignoring the importance of agency in everyday life (1971: 49). Only in recent times and amid the new contexts of topics such as 'embodiment', 'ritual' and 'collective identity' has Durkheim's significance as classic (re)emerged (Alexander and Smith 2005). 
The opposite might be said of Simmel, who never became fully canonical, largely because of Parsons' aversion to his unsystematic, impressionistic style of writing. This feature of Simmel's work was at odds with Parsons' ambition to establish a canon for sociology as a 'science of society'. Yet, while Simmel has appeared only intermittently as part of the canon, and then mostly as an afterthought to the famous three, it is his writing style that now renders him classic to those who see it as a forerunner of an appropriately 'fractured' postmodernist sociology (Deflem 2003; Frisby 1992).

Although I do not explore this extensively here, the differences drawn between canons and classics parallel those Margaret Archer draws between culture (structure) and agency in her Critical Realist sociology $(1989 ; 1995 ; 2000)$. She emphasises the irreducibly distinct but real nature of these phenomena, arguing that we can only understand the relation between the two properly by holding to the distinction. Failing to do this inevitably leads to conflation in favour of one or the other. Hence, although in actual situations, canons and classics intertwine and mutually influence each other, they are analytically separate, speak of different things, and are explainable in different ways. 'Canon' refers to the collection of texts through which a discipline organises its identity and is part of the wider Cultural System. It is situated within the institution of (higher) education, which is structurally related to, and affected, by other parts of the Social System.

'Classic' on the other hand, belongs on the side of agency. Its capacity to 'speak' afresh is dependent on agents capable of 'hearing' what it has to say. Indeed, insofar as it is not a statement about the past, but says something about the present as if specifically to it, it exists in a dialogic relation with current agents and thus in a certain sense has agentic properties itself. Because the classic is not determined by the structural scaffolding of the canon, but is the outcome of this dialogue it does not exist above critical suspicion as its opponents argue. The classic can be challenged; though in being capable of preserving 'difficulty' can equally challenge our assumptions of current superiority. 


\section{Conclusion}

In many instances, disputes over the future of the classic and the canon have been confused by the failure to distinguish adequately between them. Critics have often subsumed classics into the canon and charged them with being little more than political bolsters for the ethnocentric and androcentric tradition of western thought. On the other hand, defenders have often relied on rhapsodic, essentialist views to make their case for the classic. The hermeneutic account of classicity does not prescribe which texts should or should not count as classic, but rather affirms the possibility of classic-ness and in this, why classics exist. It provides an alternative way of conceiving matters, one able to acknowledge the inner connection between a text's 'eminence' and its 'historicity' as these happen within the horizons of tradition. The implication is clear, both Kermode's 'sense of an ending' and Steiner's corresponding pessimism are misleading. Gadamer uses the word 'einleuchten', meaning to 'shine out', to highlight the way the eminent or classic text presents itself to us. We dwell on such texts because we find them illuminating. The idea is familiar in English too; we unselfconsciously refer to some texts as insightful or of throwing light on things or of having clarified matters. This notion of luminosity as attaching to some texts echoes the wider hermeneutic rationale for classics. If the temporal nature of human existence is as Gadamer describes, then classics are the clearest expression of the ontological link between past and present, and as such, their persistence is inevitable. Moreover, while classics are not above critical suspicion, their persistence is not only inevitable, but also desirable, as it underwrites the vitality of tradition. Tradition, thought this way, is not mere continuity but an ongoing tension between past and present made vivid by the sometimes 'difficult' questions classics ask of us in the here and now. 


\section{$\underline{\text { References }}$}

Amann P (Ed.) (1963) The Eighteenth Century Revolution: French or Western?

Lexington Massachusetts: D. C. Heath and Company

Alexander, J. (1987) 'The Centrality of the Classics', in Social Theory Today edited by Anthony Giddens, Cambridge: Polity Press

Alexander, J. C. and Smith P. eds. (2005) The Cambridge Companion to Durkheim, Cambridge: Cambridge University Press

Archer, M. (1989) Culture and agency: The Place of Culture in Social Theory, Cambridge: Cambridge University Press

Archer, M. (1995) Realist Social Theory: The Morphogenetic Approach, Cambridge: Cambridge University Press

Archer, M (2000) Being Human: The Problem of Agency, Cambridge: Cambridge University Press

Baehr, P. (2002) Founders, Classics, Canons: Modern Disputes over the Origins and Appraisal of Sociology's Heritage, London: Transaction Publishers

Bloom, H. (1994) The Western Canon: The Book and School of the Ages, New York: Riverhead Books

Bourdieu, P. (1988) Homo Academicus, translated by Peter Collins, Cambridge: Cambridge University Press

Caputo, J. (1987) 'Gadamer's Closet Essentialism: a Derridean Critique', in Dialogue and Deconstruction: The Gadamer - Derrida Encounter edited by Diane P. Michelfelder and Richard E. Palmer, New York: State University of New York

Collins, R. (1997) 'A Sociological Guilt Trip: a reply to Connell', American Journal of Sociology, 102(6): 1558-64

Connell, R. W. (1997) 'Why is Classical Theory Classical', American Journal of Sociology, 102(6): 1151-57

Davey, N. (2006) Unquiet Understanding: Gadamer's Philosophical Hermeneutics, Albany: State University of New York Press

Deflem, M (2003) 'The Sociology of the Sociology of Money: Simmel and the Contemporary battle of the Classics', Journal of Classical Sociology, 3(1): 67-96 
Douglas, J. Ed. (1971) Understanding Everyday Life: Toward the Reconstruction of Sociological Knowledge, London: Routledge and Kegan Paul

Eagleton, T. (1983) Literary Theory: An Introduction, Oxford: Basil Blackwell

Frisby, D. (1992) Simmel and Since: Essays on Georg Simmel's Social Theory, London Routledge

Gadamer, H-G. (1976) Philosophical Hermeneutics, translated and edited by David E. Linge, Berkeley: University of California Press

Gadamer, H-G (1989) Truth and Method, second revised edition translated by J Weinsheimer and D. G. Marshall, London: Sheed and Ward

Gadamer, H-G (1990) 'Reply to my critics' in The Hermeneutic Tradition: from Ast to Ricoeur, edited by Gayle L. Ormiston and Alan D. Schrift, New York: State University of New York Press

Gadamer, H-G. (2001) 'Aesthetics', in Gadamer in Conversation: Reflections and Commentary, edited and translated by Richard E. Palmer, interview with Carsten Dutt, New Haven: Yale University Press

George, T. (2009) What is the Future of the Past? Gadamer and Hegel on Truth, Art and the Ruptures of Tradition', Journal of the British Society for Phenomenology, 40(1): 4-20

Gorak, J (1991), The Making of the Modern Canon: Genesis and Crisis of a Literary Idea, London: Athlone Press, 1991.

Guillory, J. (1993) Cultural Capital: The Problem of Literary Canon Formation, London: University of Chicago Press

Grondin, J. (2003) The Philosophy of Gadamer, translated by Kathryn Plant, Chesham Bucks Acuman Publishing Limited

Habermas, J. (1988) On the Logic of the Social Sciences, translated by Shierry Weber Nicholson and Jerry A. Stark, Cambridge: Polity Press with Basil Blackwell

Habermas, J. (2004) 'Public Space and Political Public Sphere - the biographical of two motifs in my thought', commemorative lecture, Kyoto, $11^{\text {th }}$ November 2004, see Habermas Forum online

Hallberg, Von, R. (1984) Canons, Chicago: University of Chicago Press 
How, Alan R. (1995) The Habermas-Gadamer Debate and the Nature of the Social, Aldershot: Avebury Ashgate

Jauss, H. R. (1982) Towards and Aesthetic of Reception, translated by Timothy Bahti, Minneapolis: University of Minnnesota Press

Kermode, F. (1967) The Sense of an Ending: Studies in the Theory of Fiction, Oxford: Oxford University Press

Lovejoy, A. O. (1960) The Great Chain of Being: A Study of the History of an Idea, New York: Harper Torchbooks

Lyotard, J-F, (1984) The Postmodern Condition: a Report on Knowledge, translated by G. Bennington, Manchester: Manchester University Press

Marshall, B. and Witz, A. (Eds). (2004) Engendering the Social: Feminist Encounters with Sociological Theory, Maidenhead UK: Open University Press

Mouzelis, N (1997) 'In defence of the sociological canon: a reply to David Parker, The Sociological Review, 45(2): 244-53

Outhwaite, W. (2009) 'Canon Formation in late 20' Century British Sociology, Sociology, 43(6): 1029-1045

Parker, D. (1997) 'Viewpoint: Why Bother with Durkheim: teaching sociology in the 1990s', The Sociological Review, 45(1): 122-46

Poggi, G. (1996) 'Lego Quia Inutile: An Alternative Justification for the Classics', in Social Theory and Sociology, edited by Stephen P. Turner, Oxford: Blackwell Publishers Ltd

Ricks, C. (1989) 'What is at Stake in the "Battle of the Books", New Criterion

Schleiermacher, F. (1998) Hermeneutics and Criticism and Other Writings, edited by Andrew Bowie, Cambridge: Cambridge University Press

Scheibler, I. (2000) Gadamer: Between Heidegger and Habermas, Oxford: Rowman and Littlefield Publishers

Skinner, Q. (1969) 'Meaning and Understanding in the History of Ideas', History and Theory, 8(1): 3-53

Smith, Barbara H. (1988) Contingencies of Value: Alternative Perspectives for Critical Theory, Cambridge Mass: Harvard University Press

Steiner, G. (1997) Errata: An Examined Life, London: Weidenfeld and Nicolson 
Tompkins, J. (1985) Sensational Designs: The Cultural Work of American Fiction 17901860, Oxford: Oxford University Press

Wagner, I. (1984) 'Hans Robert Jauss and Classicity’, Modern Language Notes, 99(5), 1173-84

Weinsheimer, J. (1991) Philosophical Hermeneutics and Literary Theory, New haven: Yale University Press

\section{Notes}

\footnotetext{
${ }^{1}$ See Kermode (1967)

${ }^{2}$ The literature on this topic is vast, but the following illustrate the arguments. For a fervent defence of the intrinsic value of the literary canon, see Bloom (1994). In contrast, Tompkins (1985) argues that literary writers wrote to secure the interest of particular audiences, rather than for aesthetic reasons. For a critique of essentialist accounts of classic literary texts informed by Bourdieu's concept of 'cultural capital', see Guillory (1993). For a bitter rejoinder to Guillory, see Ricks (1989: 40-44). Smith (1988) argues similarly to Guillory, that the value we attribute to canonical texts is really the outcome of a collective cultural decision. For an excellent response to views that subsume the classic into the canon, see Weinsheimer (1991: chapter 6). For a measured account of the desirability of canons, see Gorak (1991).

${ }^{3}$ One of the best defences of the classic text in Sociology is Alexander (1987). In contrast Connell (1997: 1511-57) takes the discipline to task for uncritically absorbing Marx, Weber and Durkheim into its canon when their work expresses the ideological assumptions of late $19^{\text {th }}$ century colonial Europe. In reply to Connell, see Collins (1997: 1558-64). Like Connell, Parker (1997) takes a critical view of the sociological canon, to which Mouzelis (1997) responded. Marshall and Witz (2004) take the classic authors to task for their 'masculinist' assumptions. Outhwaite (2009) examines the growth in the canonical status of Bauman, Beck, Bourdieu and Giddens in late $20^{\text {th }}$ century Britain. The most extensive overview of the issue generally is in Baehr (2002)

${ }^{4}$ Although it does not affect Bloom's overall argument about the excellence of classic texts, there is more dispute over the authorship of Shakespeare's plays than he allows. Even if we bypass questions of intertextuality, recent scholarship indicates that parts of Macbeth were written by Thomas Middleton. See...

${ }^{5}$ Instead, Bourdieu locates Sociology alongside other new disciplines such as Ethnology and Linguistics, or peripheral ones such as Assyriology and Egyptology, as disciplines where "consecrated heretics" may be found. The point is part of his wider argument that higher education is stratified between those who commit to research and are academically successful, and those who are less academically successful but determine courses and syllabuses and are often involved in management and administration. Roughly speaking, the former generate symbolic capital, while the latter possess power. Sociology has its "consecrated" intellectuals, even though, on his account it lacks the status of being a fully canonical discipline.

${ }^{6}$ Other authors who challenge the view of Gadamer's "tradition" as conservative include Scheibler (2000) and George (2009)

7 Jauss's later ideas change and draw much closer to those of his erstwhile teacher, Gadamer. For an account of these changes see Wagner (1984)

${ }^{8}$ There is some dispute over the term, subtilitas applicandi, as it does not appear directly in Rambach's Institutiones Hermeneuticae Sacrae (1723). The idea of 'application' is nevertheless present in his work. See Grondin (2003: 166-67, note 52)
} 
